\title{
Statement of ReVenue aNd EXPENDITURe
}

\section{REVENUE}

For the Year Ending 30th June 1954

Investment Interest Earned $\$ 24.00$

Bank Interest

\section{EXPENDITURE}

Prize-University of Toronto-1953-1954

Bank Charges

Excess of Expenditure OVER REVENUE

\section{RESOLUTIONS ADOPTED AT THE ANNUAL MEETING OCTOBER 1954}

\section{Resolution No. 1}

Wreress, The protection of our forest resource is an urgent national problem; and,

WhereAs, Under Section 6 of the Canada Forestry Act, the Minister of Northern Affairs and National Resources may, with the consent of the Governor in Council, enter into agreements with any Province for the protection of that resource; and,

WhRREAs, This phase of forest conservation, by co-operation between Federal and Provincial Governments, has not been implemented;

Tarrefore, be IT resolved, That this situation be drawn to the attention of the individual sections of the Canadian Institute of Forestry with the suggestion that they determine the advisability, in respect to areas in which they are directly interested, of taking immediate action (1) to inform their local Members of Parliament of (a) the national significance of the problem of forest protection, and (b) the urgency of dealing with that problem adequately on a uniform basis, and (2) to inform their local Members of Legislative Assemblies of (a) the importance of forest protection in their provincial orbit, and (b) of the need for concerted action on the part of all Provinces to establish this as an urgent national problem.

\section{Resolution No. 2}

Whereas, The members and sub-committees, of the Vancouver Island Section, working on the Annual Meeting preparations have done outstanding work on behalf of the Institute; and,

WhEREAS, The press and radio have given singular co-operation;

THEREFORE, BE IT RESOLVED, That a hearty vote of thanks be extended to all those contributing to this most successful meeting. 